\title{
Squamous Cell Carcinoma of Lung with Osteo-Cartilaginous Metaplasia: A Case Report and Review of the Literature
}

\author{
Akciğerin Osteokartilajinöz Metaplazili Skuamöz Hücreli Karsinomu: \\ Olgu Sunumu ve Literatürün Gözden Geçirilmesi
}

\author{
Rumana MAKHDOOMI, Khalil BABA, Rayees MALIK, Suhail MALIK, Mohsin RASOOL, Basharat MUBEEN \\ Department of Pathology, Sheri-Kashmir Institute of Medical Sciences (SKIMS), SRINAGAR, INDIA
}

\begin{abstract}
Calcification and ossification are very rare in primary squamous cell carcinoma of the lung. We report a 55-year-old male with primary squamous cell carcinoma of the lung who on histopathological examination was seen to have extensive calcification and ossification. Squamous carcinoma of the lung rarely presents with osteocartilaginous metaplasia. The case is presented here for its unique presentation.
\end{abstract}

Key Words: Calcification, Squamous cell carcinoma, Lung carcinoma

\section{ÖZ}

Akciğerin primer skuamöz hücreli karsinomunda kalsifikasyon ve ossifikasyon çok nadirdir. Histopatolojik incelemede yaygın kalsifikasyon ve ossifikasyon görülen primer skuamöz hücreli akciğer karsinomu bulunan 55 yaşında bir erkek hastayı sunuyoruz. Akciğerin skuamöz hücreli karsinomu nadiren osteokartilajinöz metaplazi gösterir. Vaka bu nadir özelliği nedeniyle sunulmuştur.

Anahtar Sözcükler: Kalsifikasyon, Skuamöz hücreli karsinom, Akciğer karsinomu

\section{INTRODUCTION}

Calcification has long been a determinant in the radiologic distinction of a benign pulmonary mass (1). However, there has been great interest in exceptions to this rule. To date, a number of primary and metastatic lung tumors have been reported to contain calcification (2). A large variety of neoplasms can produce calcified lung metastasis (2). Pulmonary adenocarcinoma is a common malignancy that is prone to calcification though bone formation in primary lung adenocarcinoma is extremely rare (3). Calcification and ossification is very rare in primary squamous cell carcinoma of the lung. We hereby report a case of squamous carcinoma of the lung with osteocartilaginous stroma (4).

\section{CASE REPORT}

A 55-year-old male presented to us with the chief complaints of episodic dry cough for the last two years and three episodes of hemoptysis during the past one year. The patient was a smoker. On examination, the patient was pale but his general physical examination was otherwise normal except grade III clubbing. His respiratory rate was $32 / \mathrm{min}$. The right side of his chest was moving more than the left side with impaired percussion note in right intramammary and infrascapular area and on auscultation, there was decreased

(Turk Patoloji Derg 2014, 30:149-151)

Received : 15.05.2011 Accepted : 24.07.2011 air entry in right inframammary and infrascapular area with fine crepitations. His abdominal examination and his CNS examination were normal. The chest X-ray showed a well defined rounded mass lesion in the right lower zone with air-fluid level (Figure 1). Contrast enhanced

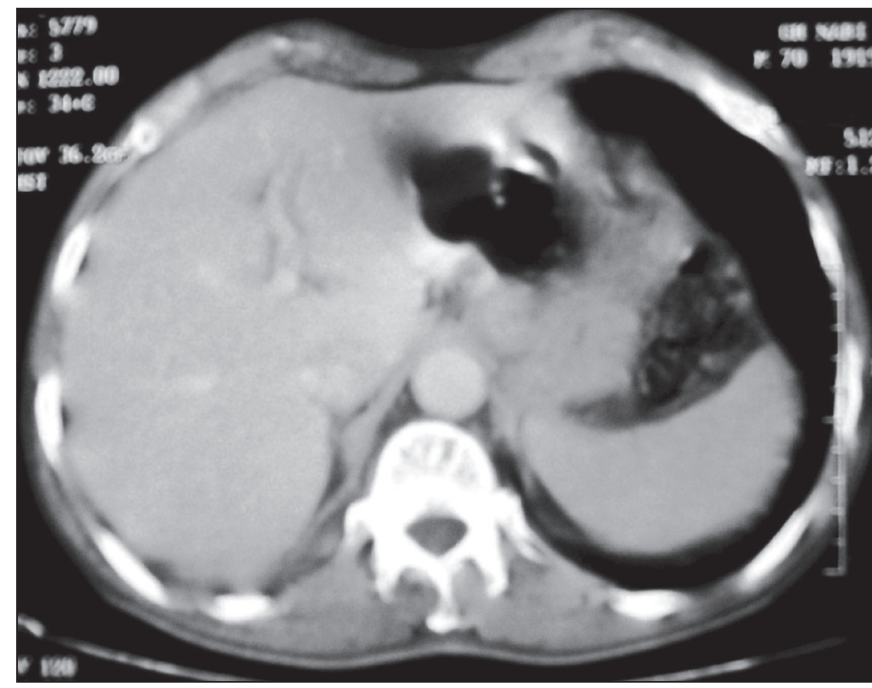

Figure 1: Contrast enhanced computed tomography (CECT) chest showing a well defined rounded cavitatory mass lesion in right lower lobe with enhancement of wall and air fluid level seen with eccentric calcification.

Correspondence: Rumana MAKHDOOMI

Department of Pathology, Sheri-Kashmir Institute of Medical Sciences (SKIMS), SRINAGAR, INDIA

E-mail: rumanahamid@rediffmail.com Phone: +91 1942400621 
computed tomography (CECT) chest showed a right lower lobe cavitatory lesion with enhancement of wall and air fluid level with eccentric calcification in the wall. The wall thickness of the lesion at the thickest area was $20 \mathrm{~mm}$. There was mild right pleural effusion. Bronchoscopy showed chronic inflammatory changes only. Fine needle aspiration cytology (USG guided) showed features of squamous cell carcinoma.

Operative findings showed a large $15 \times 10 \mathrm{~cm}$ growth seen in the right lower lobe involving the right middle lobe with multiple hilar lymph nodes. The growth was seen adherent to the chest wall. Lobectomy was done and the lesion was removed in toto.

On gross examination of the lobectomy specimen there was a large tumor measuring $10 \times 15 \mathrm{cms}$. The cut surface of the

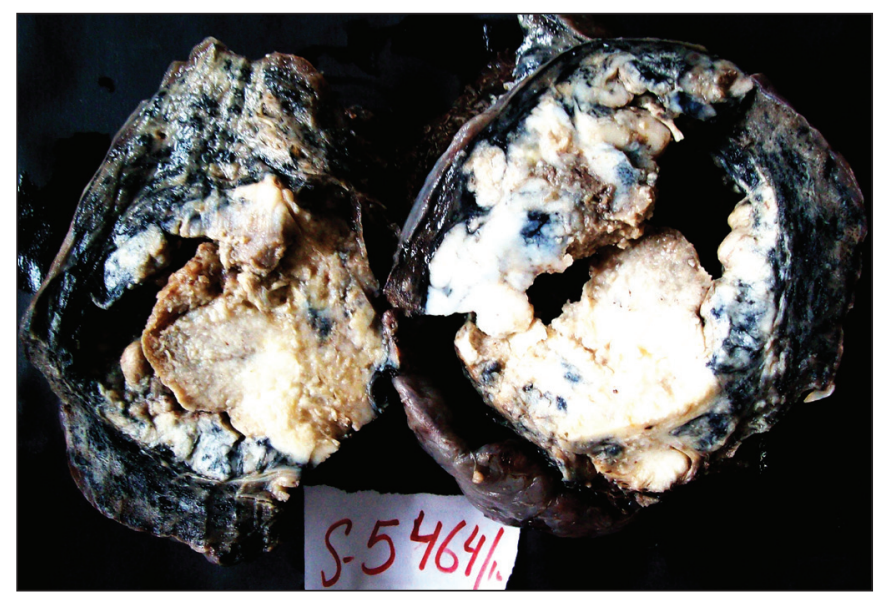

Figure 2: Gross appearance showing a large globular grey-white tumor adherent to pleura.

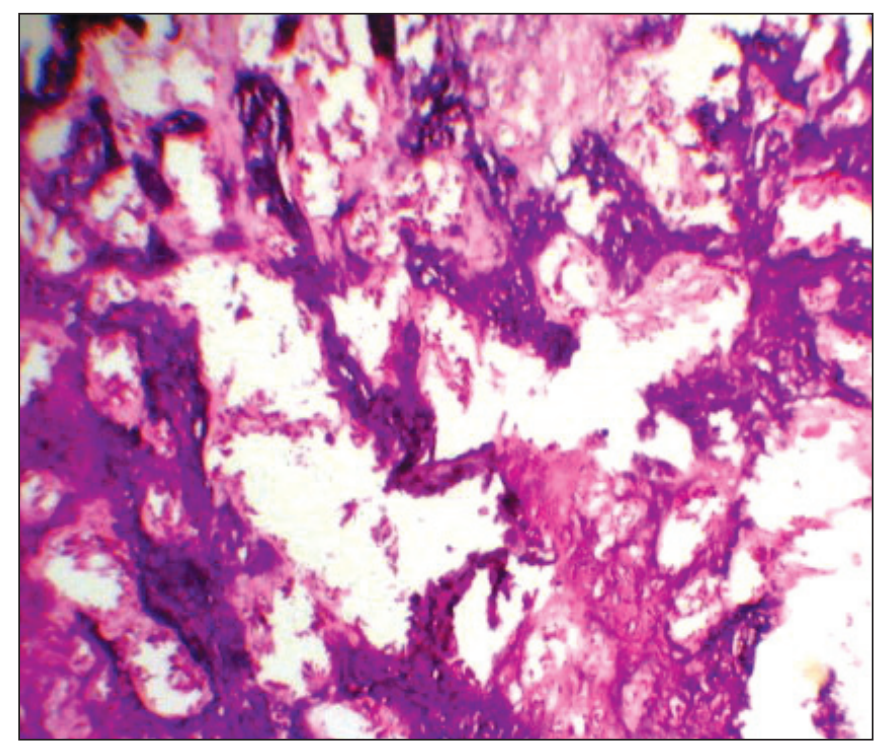

Figure 3: Areas of dense calcification and ossification within the tumor (H\&E x20). tumor was grayish yellow with interspersed grayish brown areas. In some areas, the tumor was hard and gritty while at places it was soft and friable (Figure 2).

On microscopic examination, the tumor was comprised of anaplastic squamous cells with areas of keratinization forming keratin pearls. There were large areas of cartilage formation within the tumor and areas of extensive calcification and ossification (Figure 3,4). The diagnosis on

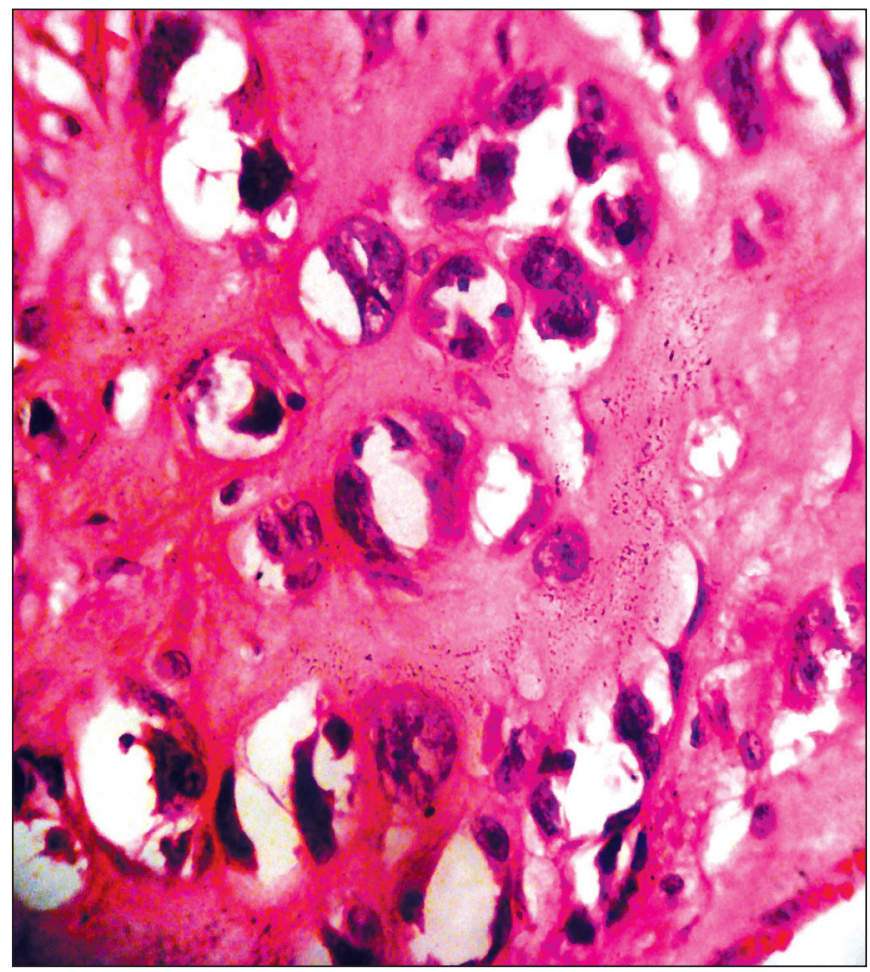

Figure 4: Sections showing cells with chondroid differentiation (H\&E x40).

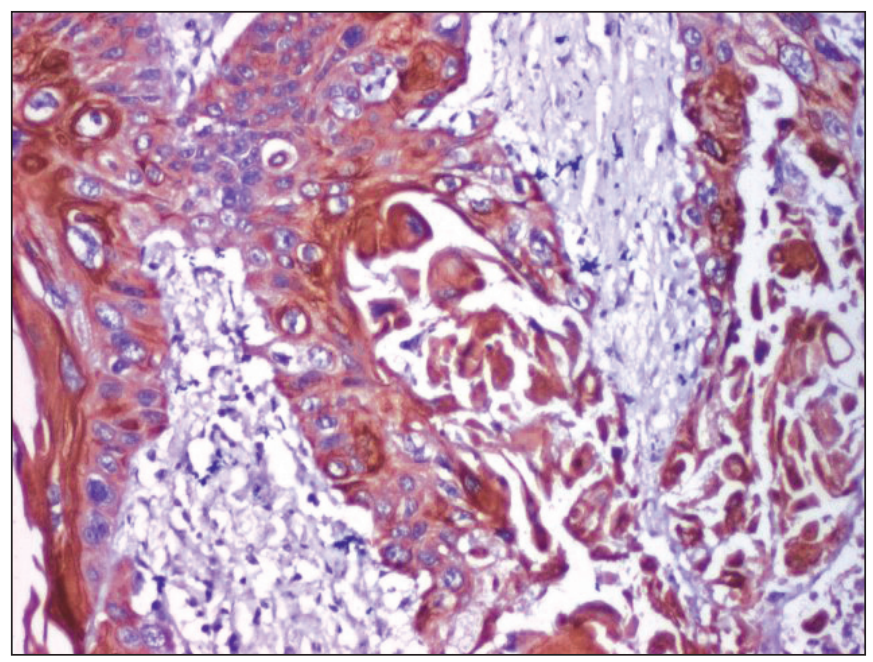

Figure 5: Sections showing malignant squamous cells with a strong reactivity for cytokeratin (Immunostain x40). 
haematoxylin and eosin stained sections showed features of well differentiated squamous cell carcinoma with oseocartilaginous metaplasia. On immunohistochemistry, there was cytokeratin positivity but the areas with osseous and cartilaginous metaplasia were negative for the cytokeratin (Figure 5).

\section{DISCUSSION}

Calcification within cancers of the lung occurs by three mechanisms: Calcified scar tissue or granulomatous disease engulfed by tumor, dystrophic calcification within areas of tumor necrosis and calcium deposition within the tumor as a result of the secretory function of the carcinoma itself (5).

Radiographicidentification of calcium within bronchogenic carcinoma is uncommon with a reported prevalence of $1 \%$ to $6 \%(5,6)$. Dystrophic calcification occurs in the necrotic areas of the cancer, and heterotopic ossification with primary lung carcinomas is extremely rare. Bronchial carcinoid is a calcifying tumor and heterotopic ossification may be seen in pulmonary adenocarcinoma (3). Heterotopic calcification in primary lung adenocarcinoma was first described by McLedon in 1985. Calcification with heterotopic bone formation may also be seen in pulmonary metastasis (2). Primary squamous cell carcinoma of lung is rarely associated with osteocartilaginous metaplasia (3).

Flanagan $\mathrm{P}$ in 1965 (4) reported osteocartilaginous metaplasia in the stroma in a 46-year-old patient with primary squamous cell carcinoma of the lung. The diagnosis in this case was however made on autopsy. The tumor was $15 \mathrm{~cm}$ in diameter and filling the left hemithorax whereas in our case one dimension of the tumor was also $15 \mathrm{~cm}$ but it was arising from the right side. This patient was subjected to radiation whereas in our patient radiation was not given. Two means of osteogenesis are known in tumors: intamembranous bone formation and endochondral bone formation. Both processes feature the transformation of a primary trabecular network into mature bones but differ in terms of starting point: whereas intramembranous bone formation involves the transformation of a mesenchymal template into bone, endochondral ossification involves the replacement of pre-existing hyaline cartilage template into bone. Heterotopic ossification of primary pulmonary adenocarcinoma has been postulated to occur via intramembranous bone formation induced by the tumor cells (3). In an extensive review of 2269 surgically resected primary lung carcinomas by Shoji, 33 cases with heterotopic ossification, including 15 cases with intratumoral heterotopic ossification (IHO) and 18 cases with extratumoral heterotopic ossification (EHO) were identified (7). All cases with IHO were adenocarcinomas and 10 of $15(66.6 \%)$ cases had confirmed positive mucin staining in the tumor cells. Calcification and ossification in squamous cell carcinoma of lung has not been studied in detail being very rare and its pathogenesis is still elusive. It is important to exhaustively sample lung tumors because there may be areas showing calcification and ossification which may be misinterpreted as a tumour arising from bone or cartilage if areas showing classical morphology of squamous cell carcinoma are not sampled.

\section{REFERENCES}

1. McLendon RE, Roggli VL, Foster WL Jr, Becsey D. Carcinoma of the lung with osseous stromal metaplasia. Arch Pathol Lab Med. 1985;109:1051-3.

2. Maile CW, Rodan BA, Godwin RJ, Jamest T, Chen T, Ravin CE. Calcification in pulmonary metastases. Br J Radiol. 1982;55: 108-13.

3. Kim GY, Kim J, Kim TS, Han J. Pulmonary adenocarcinoma with heterotopic ossification. J Korean Med Sci. 2009;24:504-10.

4. Flanagan P, McCracken AW, Cross RM. Squamous carcinoma of the lung with osteo-cartilaginous stroma. J Clin Path. 1965; 18:403-7.

5. Mahoney MC, Shipley RT, Corcoran HL, Dickson BA. CT demonstration of calcification in carcinoma of the lung. AJR. 1990;154:255-8

6. Theros EG. 1976 Caldwell Lecture: Varying manifestation of peripheral pulmonary neoplasms: A radiologic-pathologic correlative study. AJR. 1977;128:893-914.

7. Kuribayashi H, Tsuta K, Mizutani E, Maeshima AM, Yoshida Y, Gemma A, Kudoh S, Asamura H, Matsuno Y. Clinicopathological analysis of primary lung carcinoma with heterotopic ossification. Lung Cancer. 2009;64:160-5. 